\title{
Economic Performance of Different IFS Components under Different Conditions of North Eastern Transition Zone of Karnataka
}

\author{
Praveen Kote $^{1 *}$, D.M. Chandargi ${ }^{2}$ and B.M Chittapur ${ }^{3}$ \\ ${ }^{1}$ Department of Agricultural Extension Education, University of Agricultural Sciences, \\ Raichur (Karnataka), India \\ ${ }^{2}$ Agriculture College Raichur, Department of Agricultural Extension Education, University of \\ Agricultural Sciences, Raichur (Karnataka), India \\ ${ }^{3}$ Department of Agronomy, University of Agricultural Sciences, Raichur (Karnataka), India \\ *Corresponding author
}

\section{Keywords \\ Economic, \\ Performance, \\ Dryland, Irrigated. \\ IFS, Yield, Returns/ rupee of investment}

\section{Article Info}

Accepted:

26 July 2020

Available Online:

10 August 2020

\section{A B S T R A C T}

Traditional farming system used by farmers in India are based on centuries of experience characterized by mixed farming involving crop production with one or more enterprises like dairy, poultry, sericulture, piggery, sheep, goat, fisheries and bee-keeping. The main aims were to achieve stability of production, provide subsistence for the family and guard against weather aberrations and other environmental stresses. In recent years, farming system gave scientific touch to the existing practices and found ways and means to make it sustainable in changing global scenario. To explore the components in farming system the study was undertaken in North Eastern Transition Zone of Karnataka, to know the different economic performance of different components followed by IFS farmers. The list of farmers practicing IFS has been prepared and categorized into dryland and irrigated conditions based on discussion with field facilitators, Agriculture officers and Horticulture officers. There are around 180 farmers practicing integrated farming system were selected randomly, of which 90 farmers comes under dryland and 90 farmers under irrigated condition. The findings under dryland condition shows that, yield of jowar was $12.25 \mathrm{q} / \mathrm{ha}$ and returns per rupee of investment was 1.28 , whereas yield of soyabean was $12 \mathrm{q} / \mathrm{ha}$ and returns per rupee of investment was 1.15 followed by redgram $(11.25 \mathrm{q} / \mathrm{ha}$ and 1.74$)$ and greengram $(11 \mathrm{q} / \mathrm{ha}$ and 1.63$)$. The findings under irrigation condition show that, the yield of flower crops was $82.50 \mathrm{q} / \mathrm{ha}$ and returns per rupee of investment was 2.52 followed by papaya (1655 q/ha and 2.23), banana (1450 q/ha and 2.25) and mango (542.5 q/ha and 2.13) respectively.

\section{Introduction}

The most significant achievement in India after independence is the self reliance in food grain production. The use of high yielding varieties, irrigation facilities, higher application of fertilizers and pesticides contributed to sufficient food grain production 
in the mid 60's and 70's of the last century. Later on development in the other enterprises like dairy, poultry, piggery, fishery, goat farming, sericulture etc., took place in an isolated manner. However the productivity of high yielding varieties and hybrids became stagnant during last decade and with limited scope for increasing the cultivable land and the country's food security is likely to be threatened in the future. The human population of India has increased to 1210.2 million at a growth rate of 1.76 per cent in 2011 over 2001 (1028.7 million) and is estimated to increase further to 1530 million by 2030 (Census of India, 2011). There are projections that demand for food grains would increase from 234 million tonnes in 2009-10 to 345 million tonnes in 2030 (Government of India, 2009). Hence, in the next two decades the production of food grains needs to be increased @ 5.5 million tons annually. Simultaneously, the demand for high-value commodities viz., fruits, vegetables, livestock products, fish, poultry etc., are increasing faster than food grains and is expected to increase by 100 per cent by 2030. To tackle this situation diversification of crop is very necessary to utilize unexplored and little explored resources to raise the income. The goal of diversification in agriculture is to stabilize the farm income particularly on small farms and to withstand the challenges of trade liberation. Therefore, crop diversification from less remunerative to more remunerative crops, need based, demand driven, location specific and national goal seeking is a continuous and dynamic concept, which involves spatial, temporal, value addition and resource complementary approaches. This diversified food basket will provide food security and improve the quality of life by adding to nutritional status of people. Therefore in the present paper an attempt has been made to assess the performance of crop components in dryland and irrigated condition under IFS.

\section{Materials and Methods}

To address the above mentioned issues, the paper uses findings of the study carried out in North Eastern Transition Zone of Karnataka during 2019-20. The Zone consists of two districts viz. Bidar and Kalaburagi. Taluks selected for the study were Bidar, Humanabad, Bhalki, Basavakalyan from Bidar district, Chincholi and Aland from Kalaburagi district. For the present study, multistage random sampling procedure was adopted for selection of sample farmers. In first stage, four taluks from Bidar district and two taluks from Kalaburagi districts were selected. In the second stage, a list of hoblis where more number of integrated farming system farmers has been prepared in consultation with officials of Department of Agriculture and Department of Horticulture working in the respective districts and also personal visits to KVKs, RSKs and some of the IFS farmers, the list of farmers actually practicing IFS and hoblis have been selected from each selected taluks. Further 3 hoblis were selected based on maximum number of IFS practicing farmers under each selected tuluks, thus making a total of 18 hoblis. Nine hoblis explicitly Mannalli, Bagdal, Janwada from Bidar taluk, Bhalki, Halbarga, Khatak Chincholi from Bhalki taluk and Nirna, Hallikhed B, Humnabad from Humanabad taluk were selected under irrigated condition. Similarly, Hulasur, Mudabi, Basavakalyan from Basavakalyan taluk, Aland, Kajoni, Nimbarga from Aland taluk and Chincholi, Kodli and Sulepet from Chincholi taluk were selected under dryland condition.

From each hobli ten farmers were selected randomly thus making of 90 sample size of IFS practicing farmers under irrigated condition. Similar procedure was followed for selection of dryland IFS practicing farmers, hence making a total sample size of 180 farmers for the study. 
The data was collected on major component under IFS through personal interview method with the help of interview schedule in an informal atmosphere either in home or field. The data collected was represents the yield and returns/ rupee of investment.

\section{Results and Discussion}

The yield and return/ rupee of investment of major IFS components under dryland and irrigated condition was presented in Table 1 and 2 respectively. The major corps under dryland condition was redgram, black gram, soya bean, green gram and Bengal gram under pulse crops and jowar belongs to cereal crop. Further in irrigated condition redgram, black gram, soya bean, Sugar cane, green gram and Bengal gram under pulse crops and jowar belongs to cereal crop. Whereas mango, papaya, banana and flower crops belongs to horticulture crops.

The data presented in Table 1 revealed the yield and returns per rupee of investment, the yield of jowar was $12.25 \mathrm{q} / \mathrm{ha}$ and returns per rupee of investment was 1.28 , whereas yield of soyabean was $12 \mathrm{q} / \mathrm{ha}$ and returns per rupee of investment was 1.15 followed by redgram (11.25 q/ha and 1.74) greengram (11 q/ha and 1.63), blackgram (10.75 q/ha and 1.39), and bengalgram (10.50 q/ha and 1.28). In dryland condition the availability of irrigation water is very less or almost negligible and farmers' depend up on rain water directly for crop cultivation. Rain water was not available during the survey period because there was a saviour drought and availability of rain water was also low. The highest returns per rupee of investment was noticed in jowar because the extent of inputs used in the jowar was low as compared to other crops, and it required less water compared to other crops, farmers grow rabi jowar as it is staple food crop and source of fodder component.
A glance at Table 2 revealed that data on yield and returns per rupee of investment of crop component. The yield of sugarcane was 90.55 ton/ha and returns per rupee of investment was 2.40 followed by soyabean (18.75 q/ha and 1.70), redgram (17.53 q/ha and 2.51), jowar (16.75 q/ha and 1.65), bengalgram (16.25 q/ha and 2.09) blackgram (15.50 q/ha and 1.87), greengram (14.00 q/ha and 1.90). Further it also revealed the data on horticulture component, the yield of flower crops was $82.50 \mathrm{q} / \mathrm{ha}$ and returns per rupee of investment was 2.52 followed by papaya (1655 q/ha and 2.23), banana (1450 q/ha and 2.25) and mango (542.5 q/ha and 2.13) respectively. Under irrigated condition the return/ rupee of investment was more in flower crops because of adequate favourable condition and requirement of labour is also less for growing flower crops. The greatest advantage is that, flowers needs much less land and water for production when compared to other agricultural crops and it also ensures the prices around the year. The net profit against the actual investment is much higher form flowers when compared the conventional crops and flower crops are always high in demand. The returns per rupee of investment was more under irrigated condition because even though there was a saviour drought but availability of water for irrigation was more compare to dry land farmers for irrigation purpose because maximum farmers under irrigated condition were had borewell, open well, farm pond etc. which helped them to provide irrigation during critical situation.

The data in Table 3 revealed that results of dryland farmers, 67.78 per cent of farmers possessed 2 to 3 bullocks followed by four and above bullocks $(3.33 \%)$. Whereas nearly six $(5.55 \%)$ per cent of farmers possessed one buffalo while a very less $(4.44 \%)$ per cent of farmers possessed one cow. It is interesting to know that, majority $(61.11 \%)$ 
of farmers possessed more than 3 numbers of goat/sheep while slightly more than one fourth $(26.66 \%)$ of farmers possessed two to three goat/ sheep. In case of poultry one third $(33.33 \%)$ of farmers possessed more than 3 poultry birds a meagre $(6.66 \%)$ per cent of farmers had less than 2 to 3 poultry birds.

In case of irrigated condition, two fifth (44.44 $\%$ ) of farmers possessed 2 to 3 bullocks followed by more than three $(12.22 \%)$. Further, more than two fifth (46.67\%) of farmers possessed 2 to 3 buffalos followed by more than three $(15.56 \%)$ and only 10.00 per cent of farmers possessed one buffalo. It is also be noticed from the Table slight more than one fourth $(25.56 \%)$ of farmers possessed 2 to $3 \mathrm{cow}$, while nearly seventeen $(16.67 \%)$ per cent of farmers possessed more than three cow and around sixteen (15.56\%) per cent of farmers possessed one cow. It is interesting to know that, nearly one fourth $(23.33 \%)$ of farmers' possessed more than 3 goat/sheep followed by two to three (16.67 $\%)$ and a very negligible $(3.33 \%)$ per cent of farmers possessed one 3.33 goat/sheep. In case of poultry nearly one third $(31.11 \%)$ of farmers possessed more than 3 poultry birds followed by 2 to 3 poultry bird $(11.11 \%)$.

The number of livestock maintained by farmers was depending up on the quantity of fodder produced and availability of labour force in the farming system. The possession of dairy, poultry and sheep and goat was for additional income and by-product of livestock. It is general practice of the farmers to use farm by-products as a feed to livestock and they fetches the additional income, whereas waste material of livestock used for FYM or vermicomost preparation and cow urine and dung utilized in preparation of jeevamrutha and panchagavya. In present condition livestock has become livelihood enterprise in the rural areas. Bullocks' utilisation are mainly for ploughing, levelling, furrowing, seeding and weeding and carrying compost to the fields meant for raising crops.

Table.1 Economic performance of crop component followed by IFS farmers under dryland condition

$(\mathbf{n}=90)$

\begin{tabular}{|c|l|c|c|c|c|c|c|}
\hline S. No. & \multicolumn{1}{|c|}{ Crops } & $\begin{array}{c}\text { Yield } \\
\text { (q /ha) }\end{array}$ & $\begin{array}{c}\text { Price } \\
\text { (Rs/q) }\end{array}$ & $\begin{array}{c}\text { Cost of } \\
\text { Cultivation } \\
\text { (Rs.) }\end{array}$ & $\begin{array}{c}\text { Gross } \\
\text { Return } \\
\text { (Rs.) }\end{array}$ & $\begin{array}{c}\text { Net } \\
\text { Return } \\
\text { (Rs.) }\end{array}$ & $\begin{array}{c}\text { Returns/ } \\
\text { rupee of } \\
\text { investment }\end{array}$ \\
\hline I & Pulse crops & & & & & & \\
\hline 1. & Redgram & 11.25 & 6000 & 38750 & 67500 & 28750 & 1.74 \\
\hline 2. & Blackgram & 10.75 & 4650 & 36088 & 49988 & 13900 & 1.39 \\
\hline 3. & Soyabean & 12 & 3710 & 38625 & 44520 & 5895 & 1.15 \\
\hline 4. & Greengram & 11 & 5200 & 35066 & 57200 & 22137.5 & 1.63 \\
\hline 5. & Bengalgram & 10.5 & 4920 & 37050 & 51660 & 14610 & 1.39 \\
\hline II & Cereal crop & & & & & \\
\hline 1. & Jowar & 12.25 & 3000 & 28750 & 36750 & 8000 & 1.28 \\
\hline III & Horticulture crops & & & & & \\
\hline 1 & Vegetables & & & 11000 & 18000 & 7000 & 1.64 \\
\hline
\end{tabular}


Table.2 Economic performance of different components (crop + horti) followed by IFS farmers under irrigated condition

\begin{tabular}{|c|c|c|c|c|c|c|c|}
\hline & & & & & \multicolumn{3}{|c|}{$(n=90)$} \\
\hline Sl. No. & Crops & $\begin{array}{l}\text { Yield } \\
\text { (q/ha) }\end{array}$ & $\begin{array}{l}\text { Price } \\
\text { (Rs/q) }\end{array}$ & $\begin{array}{c}\text { Cost of } \\
\text { cultivation } \\
\text { (Rs.) }\end{array}$ & $\begin{array}{c}\text { Gross } \\
\text { Return } \\
\text { (Rs.) }\end{array}$ & $\begin{array}{c}\text { Net } \\
\text { Return } \\
\text { (Rs.) }\end{array}$ & $\begin{array}{c}\text { Returns/ } \\
\text { rupee of } \\
\text { investment }\end{array}$ \\
\hline I & \multicolumn{7}{|l|}{ Pulse crops } \\
\hline 1 & Redgram & 17.53 & 6000 & 41875 & 105150 & 63275 & 2.51 \\
\hline 2 & Blackgram & 15.50 & 4650 & 38537.5 & 72075 & 33537.5 & 1.87 \\
\hline 3 & Soyabean & 18.75 & 3710 & 40875 & 69562.5 & 28687.5 & 1.70 \\
\hline 4 & Greengram & 14.00 & 5200 & 38300 & 72800 & 34500 & 1.90 \\
\hline 5 & $\begin{array}{l}\text { Sugarcane (in } \\
\text { ton) }\end{array}$ & 90.55 & 1859 & 70185 & 168332 & 98147 & 2.40 \\
\hline 6 & Bengalgram & 16.25 & 4920 & 38300 & 79950 & 41650 & 2.09 \\
\hline II & \multicolumn{7}{|l|}{ Cereal crop } \\
\hline 1 & Jowar & 16.75 & 3000 & 30500 & 50250 & 19750 & 1.65 \\
\hline III & \multicolumn{7}{|c|}{ Horticulture crops } \\
\hline 1 & Mango & 542.5 & 857 & 218582.5 & 464922.5 & 246340 & 2.13 \\
\hline 2 & Papaya & 1655 & 418 & 309915 & 691790 & 381875 & 2.23 \\
\hline 3 & Banana & 1450 & 425 & 274220 & 616250 & 342030 & 2.25 \\
\hline 4 & Flower crop & 82.5 & 2932 & 95982.5 & 241890 & 145907.5 & 2.52 \\
\hline
\end{tabular}

Table.3 Distribution of IFS farmers according to their livestock possession under dryland and irrigated conditions

\begin{tabular}{|c|c|c|c|c|c|c|c|}
\hline \multirow[t]{2}{*}{ Conditions } & \multirow[t]{2}{*}{ Category } & \multicolumn{2}{|c|}{$\begin{array}{c}\text { livestock } \\
\text { possession (1) }\end{array}$} & \multicolumn{2}{|c|}{$\begin{array}{c}\text { livestock } \\
\text { possession (2 to } 3)\end{array}$} & \multicolumn{2}{|c|}{$\begin{array}{c}\text { livestock } \\
\text { possession (4 } \\
\text { and above) }\end{array}$} \\
\hline & & f & $\%$ & f & $\%$ & $\mathbf{f}$ & $\%$ \\
\hline \multirow{5}{*}{$\begin{array}{l}\text { Dryland } \\
\text { condition }\end{array}$} & Bullock & -- & -- & 61 & 67.78 & 3 & 3.33 \\
\hline & Buffalo & 5 & 5.55 & -- & -- & -- & -- \\
\hline & Cow & 4 & 4.44 & -- & -- & -- & -- \\
\hline & Sheep/Goat & -- & -- & 24 & 26.66 & 55 & 61.11 \\
\hline & Poultry & -- & -- & 6 & 6.66 & 30 & 33.33 \\
\hline \multirow{5}{*}{$\begin{array}{l}\text { Irrigated } \\
\text { condition }\end{array}$} & Bullock & -- & -- & 40 & 44.44 & 11 & 12.22 \\
\hline & Buffalo & 9 & 10.00 & 42 & 46.67 & 14 & 15.56 \\
\hline & Cow & 14 & 15.56 & 23 & 25.56 & 15 & 16.67 \\
\hline & Sheep/Goat & 3 & 3.33 & 15 & 16.67 & 21 & 23.33 \\
\hline & Poultry & -- & -- & 10 & 11.11 & 28 & 31.11 \\
\hline
\end{tabular}

Note: $\mathrm{f}=$ Frequency, $\%=$ Per cent 
Table.4 Cost and returns of livestock and component under integrated farming system

\begin{tabular}{|l|c|c|c|c|}
\hline \multicolumn{1}{|c|}{$\begin{array}{c}\text { Livestock } \\
\text { inventory }\end{array}$} & $\begin{array}{c}\text { Cost of annual } \\
\text { maintenance } \\
\text { (Rs.) }\end{array}$ & $\begin{array}{c}\text { Gross Income } \\
\text { per annum (Rs.) }\end{array}$ & $\begin{array}{c}\text { Net Income per } \\
\text { annum (Rs.) }\end{array}$ & $\begin{array}{c}\text { Returns/ rupee } \\
\text { of investment }\end{array}$ \\
\hline $\begin{array}{l}\text { Local } \\
\text { buffalo/cow }\end{array}$ & 27740 & 60000 & 32260 & 2.16 \\
\hline Cross breed cow & 46350 & 124400 & 78050 & 2.68 \\
\hline Buffalo breed & 47200 & 117900 & 70700 & 2.50 \\
\hline Sheep/goat/unit & 224250 & 493200 & 268950 & 2.20 \\
\hline Poultry / unit & 4850 & 8000 & 3150 & 1.65 \\
\hline
\end{tabular}

Note: Poultry -50 birds/ unit, Sheep/goat $-10 /$ unit, Dairy $=1$ cow/buffalo

Table.5 Economics of dairy farming followed by IFS farmers

\begin{tabular}{|c|c|c|c|c|}
\hline $\begin{array}{l}\text { Sl. } \\
\text { No. }\end{array}$ & Inputs & $\begin{array}{c}\text { Local } \\
\text { buffalo/cow }\end{array}$ & Cross breed cow & Buffalo breed \\
\hline I & $\begin{array}{l}\text { Feed/miscellaneous } \\
\text { cost }\end{array}$ & Cost (Rs) & Cost (Rs) & Cost (Rs) \\
\hline 1 & Rice bran & 3460 & 8450 & 8800 \\
\hline 2 & Feed mix & 4350 & 5850 & 6200 \\
\hline 3 & Dry fodder & 3250 & 7550 & 7800 \\
\hline 4 & Green fodder & 6530 & 12750 & 12950 \\
\hline 5 & Medicines & 650 & 1250 & 950 \\
\hline 6 & Labour & 9500 & 10500 & 10500 \\
\hline II. & Total cost production & 27740 & 46350 & 47200 \\
\hline III. & Average milk/day(lit) & 6 & 13 & 12 \\
\hline IV. & Average milk/annum(lit) & 1800 & 3900 & 3600 \\
\hline V. & Rs./lit & 32 & 31 & 32 \\
\hline VI. & Milk Rs./annum & 57600 & 120900 & 115200 \\
\hline VII. & $\begin{array}{l}\text { Returns from by- } \\
\text { products }\end{array}$ & 2400 & 3500 & 2700 \\
\hline VIII. & Total return & 60000 & 124400 & 117900 \\
\hline \multirow[t]{2}{*}{ IX. } & net return & 32260 & 78050 & 70700 \\
\hline & $\begin{array}{l}\text { Returns/ rupee of } \\
\text { investment }\end{array}$ & 2.16 & 2.68 & 2.50 \\
\hline
\end{tabular}

Note: Poultry -50 birds/ unit, Sheep/goat - up to 10/ unit, Vermicompost pit - 2 pits/unit, $\quad$ Dairy = more than 1 cow/buffalo 
Table.6 Economics of sheep/goat farming followed by IFS farmers per unit

\begin{tabular}{|c|c|c|}
\hline \multirow{2}{*}{$\begin{array}{c}\text { SI. No. } \\
\text { I }\end{array}$} & \multicolumn{2}{|c|}{ Sheep/ goat } \\
\hline & Particulars & Cost of production( $(\mathrm{Rs})$ \\
\hline 1 & Mineral mixtures & 73000 \\
\hline 2 & Medicines & 6000 \\
\hline 3 & Green fodder & 91250 \\
\hline 4 & Labour & 50000 \\
\hline 5 & Miscellaneous & 4000 \\
\hline II & Total cost of production & 224250 \\
\hline 1 & Gestation period (days) & 144 \\
\hline 2 & Dry period (days) & 32 \\
\hline 3 & Lambing & 176 \\
\hline 4 & average body weight (Kg) & 32 \\
\hline 5 & Milk Rs/lit & 75 \\
\hline III & Net Returns & 268950 \\
\hline 1 & Average limbs & 40 \\
\hline 2 & Milk yield / year for 9 eve/doe & 97200 \\
\hline 3 & Sale cost of 10 goat/sheep & 120000 \\
\hline 4 & Sale cost of limbs & 240000 \\
\hline 5 & Cost of manure & 36000 \\
\hline IV & Total return & 493200 \\
\hline $\mathbf{V}$ & Returns/ rupee of investment & 2.20 \\
\hline
\end{tabular}

Note - Per unit content 10 goats/sheep

Table.7 Economics of poultry farming followed by IFS farmers

\begin{tabular}{|c|l|c|}
\hline Sl. No. & \multicolumn{2}{|c|}{ Poultry } \\
\hline $\mathbf{I}$ & Particulars & Cost of production(Rs) \\
\hline $\mathbf{1}$ & Chick price (Rs 22/chick) & 1100 \\
\hline $\mathbf{2}$ & Cost of feed & 3250 \\
\hline $\mathbf{3}$ & Vaccination & 500 \\
\hline $\mathbf{4}$ & Total cost of production & 4850 \\
\hline $\mathbf{I I}$ & Net Return & 3150 \\
\hline $\mathbf{1}$ & Bird weight (2Kg/bird) & 100 \\
\hline $\mathbf{2}$ & Rs/Kg & 80 \\
\hline III & Total return (Rs) & 8000 \\
\hline IV & Returns/ rupee of investment & 1.65 \\
\hline
\end{tabular}

Note - Poultry -50 birds/ unit,

The data from Table 4 depicted the results on cost and returns/ rupee of investment, the cost of production for crossbreed cow was ₹ 46350 and returns/ rupee of investment was 2.68 followed by vermicompost ₹ 23762 and 2.53 , buffalo breed ₹ 47200 and 2.50 , sheep/goat ₹ 224250 and 2.20 , local buffalo or cow ₹ 27740 and 2.16 and poultry $₹ 4850$ and 1.65 
respectively. Though the cost of production was highest in buffalo breed but the return/ rupee of investment was high in cross breed cow because it yields highest milk per day as compared to other livestock and they are very susceptible to temperature and other management practices and also they have better reproductive capacity.

The results from Table 5 depicted that, an average milk yield / annum of local buffalo, cross breed and buffalo breed was 1800, 3900, 3600 litres respectively, and the feed cost of buffalo breed was higher it was mainly due to higher cost on concentrate and buffalo breeds are very much response to concentrates.

A glace from the Table 6 revealed that, cost of production for 1 unit of sheep/goat was ₹ 224250 because of cost on concentrates which is cheaper as compared to other livestock. Their cost on medicine was also low because they have better disease resistance when compared to other animals. Sheep/goat are very friendly and cheaper to maintain because green fodder given to goats about 2 to $3 \mathrm{~kg}$ per day would be sufficient. and they can adopt various agro-climatic conditions when they are integrated into agriculture along with other livestock where there manure can be utilised and they can feed on weeds also and their milk has good demand in market as it can use for various medicinal purpose.

It is observed from Table 7 that cost of production for one unit of poultry was ₹ 4850 and return was ₹ 3150 because of cost of feed and vaccination. Returns/ rupee of investment was 1.65 because poultry broilers intake of feed is comparatively low while it produces maximum possible amount of food for us and the main advantage was it has a continuous source of income. The returns/ rupee of investment was low in poultry but it gives rapid return on investment and it requires less investment.
It can be concluded that, additional enterprises with crop viz. dairy, poultry, sheep, goat rearing etc. have great potentialities in the agricultural economy. These enterprises not only supplement the income of the farmers but also help in increasing the family labour employment. It is the only way to get more income from the agriculture and allied enterprises as compared to mono-cropping. In IFS the farm wastes are better recycled used as input for other component for productive purposes. The integration of crops and livestock is a boon for low-income small-scale farmers and it uses diverse resources such as fodder legumes, crop residues and livestock manure in a system of nutrient recycling.

\section{References}

Anonymous, 2011, Census report, Ministry of Home Affairs, Government of India.

Baindha. A., Sankhala. G. and Chand. S. 2019, Entrepreneurial behaviour of milk processors Indian Res. J. Extn. Edu., 19 (2\&3): 29-31.

Baksh H., Yadav, J. N., Yadav, V. P. S., Yadav. H. and Deshwal. A. K., 2019 Profitability and production of marigold flowers in Faridabad District of Haryana, Indian Res. J. Extn. Edu. 19 (2\&3): 25-28

Chandran, R. and Sreedaya, G. S., 2018, Involvement of farm women groups in the planning, production and marketing aspects of vegetables in Kerala. J. Extn. Edu., 30 (4) : 6173 - 6176.

Desai, B. K. Satyanarayana Rao., Biradar, S. A., Prahlad, U., Shashikumar, M., Santhosh U. N. and Jagannath 2013, Development of profitable integrated farming systems for small and marginal farmers of Hyderabad Karnataka Region under irrigated condition International $J$ of Agric, Env. and Biotech., 6(4): 617-622

Kerlinger, E. N., 1978, Foundations of 
Behavioural Research, New York: Holt, Rine Hart and Winston.

Krishi Marata Vahini, 2019, krishimaratavahini.kar.nic.in research challenges and opportunities. Eastern Indian Farming System Research \& Extension, Newsletter 6(4): 3-10.

\section{How to cite this article:}

Praveen Kote, D.M. Chandargi and Chittapur, B.M. 2020. Economic Performance of Different IFS Components under Different Conditions of North Eastern Transition Zone of Karnataka. Int.J.Curr.Microbiol.App.Sci. 9(08): 3539-3547. doi: https://doi.org/10.20546/ijcmas.2020.908.408 